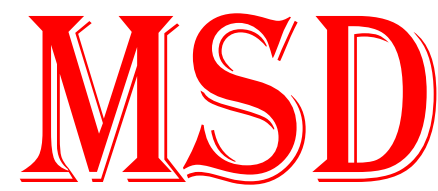

Medical Science and Discovery ISSN: 2148-6832

\section{Research Article}

Received 08-12-2021

Accepted 16-12-2021

Available Online: 17-12-2021

Published 30-12-2021

Distributed under

Creative Commons CC-BY-NC 4.0

\section{OPEN ACCESS}

\title{
Effect of some toxic metals in drinking water on male reproductive hormones
}

\author{
Fidelis Ohiremen Oyakhire ${ }^{1}$, Enehizena Osaro Ogie ${ }^{2}$, Egho Eseoghene \\ Valentine $^{3}$, Cedric Odaro ${ }^{4}$, Joy Akpesiri Egho ${ }^{4}$, Ekomobong Effiong Idem ${ }^{4}$, \\ Ibhenbisa Ighedose Benjamin ${ }^{4}$ \\ 1 Dept of Medical Laboratory Science, College of Health Sciences, Joseph Ayo Babalola University, Ikeji- \\ Arakeji, Osun State, Nigeria \\ 2 Dept of Medical Laboratory Science, University of Benin, Benin City, Edo State, Nigeria \\ 3 Dept of Clinical Chemistry, Edo Specialist Hospital, Nigeria \\ 4 Dept of Clinical Chemistry, Edo Specialist Hospital, Benin City, Edo State , Nigeria \\ * Corresponding Author: Fidelis Ohiremen Oyakhire E-mail: fooyakhire@jabu.edu.ng
}

\section{ABSTRACT}

Objective: Drinking water contaminated with toxic metals can be a leading cause of infertility in males. The aim of this study was to determine the levels of some toxic metals and trace elements in drinking water and reproductive hormone levels in males who drink water from these sources in Sabongida-Ora, Edo State, Nigeria.

Material and Methods: A total of 90 subjects consisting of 30 subjects who drink borehole water, 30 subjects who drink water from hand-dug well, and 30 subjects who drink table water, aged between 18 and 45 years, were recruited for this study. Serum reproductive hormones were analyzed using ELISA method. Blood lead, cadmium, serum zinc, and copper were analyzed using atomic absorption spectroscopy (AAS). The data obtained were analyzed using SPSS version 23.0.

Results: Blood $\mathrm{Cd}$ and $\mathrm{Pb}$ levels were significantly higher $(\mathrm{P}<0.05)$ in hand-dug, borehole and treated water consumers while serum $\mathrm{Zn}$ level was significantly lower $\mathrm{P}<0.05)$ in hand-dug well and borehole water consumers than treated table water consumers. The serum $\mathrm{Cu}$ level was not significantly different between the groups. The reproductive hormones were significantly lower among hand-dug well and borehole water consumers than treated table water consumers $(\mathrm{p}<0.05)$, while $\operatorname{PROL}(\mathrm{P}<0.05)$ was significantly higher among hand-dug well, borehole water consumers than treated water consumers. Serum PROL correlated positively with $\mathrm{Pb}(\mathrm{r}=0.443 ; \mathrm{P}<0.05)$ and negatively with serum $\mathrm{Zn}(\mathrm{r}=-0.404 ; \mathrm{P}<0.05)$ while $\mathrm{T}$ correlated positively $(\mathrm{r}=0.542 ; \mathrm{P}<0.005)$ with $\mathrm{Zn}$. Similarly, FSH correlated negatively with $\mathrm{Pb}(\mathrm{r}=-0.398 ; \mathrm{P}<0.05)$ and positively with $\mathrm{Zn}(\mathrm{r}=0.422 ; \mathrm{P}<0.05)$, while $\mathrm{LH}$ correlated inversely with $\mathrm{Cd}(\mathrm{r}=-0.622 ; \mathrm{P}<0.05)$ and positively with $\mathrm{Zn}(\mathrm{r}=0.745 ; \mathrm{P}<0.05)$. Expectedly, $\mathrm{Cd}$ and $\mathrm{Pb}$ were higher while $\mathrm{Cu}$ and $\mathrm{Zn}$ were lower in hand-dug well water consumers than borehole water consumers.

Conclusion: Water consumption from hand-dug wells may have adverse reproductive sequelae among consumers.

Keywords: Toxic metals, Reproductive hormones, water consumers

\section{INTRODUCTION}

In Nigeria, access to safe drinking water has become a great problem due to increase in population, most inhabitants have no other option but to engage borehole drillers to sink borehole for them at high cost, and other relies on dugged well water. This has posed serious health challenges, especially infertility which has become social dilemma in Subsaharan Africa like Nigeria. In most of the cases there are no water supplies and as a result the local population has to depend on shallow aquifers by installing hand pumps or installing electric motors to fetch their water needs. Mostly these new settlements are located around industrial zones. Hence they are at high risk by the effect of heavy metals due to contaminated water consumption. The supply of safe drinking water is crucial to human life, and safe drinking water should not impose a significant risk to humans (1). Although a few metals are essential for human health, an excess amount of these metals can have negative effects (2). 
Toxic metals are not only potential source of oxidants but are also endocrine disruptors. Toxic metals are released into the environment through a natural process and anthropogenic activities (chemical industries and manufacturing processes) and Industrial processes through electroplating and metal smelting. Poorly treated domestic, industrial and agricultural wastewater contains high concentrations of metals, which are often discharged into the environment and water bodies for consumption.

Some toxic metals, such as cadmium, mercury, and lead, may also enter the atmosphere due to traffic pollution and industrial activities, which can be deposited in soils around the reservoir and then enter the water along with the surface runoff (3). The sources of drinking water e.g., surface waters; groundwater and seawater are likely to be polluted by toxic metals (4). Leaching of metals from the water distribution system (WDS) can contaminate drinking water (5).

Small and rural communities and individuals often consume water with a higher level of toxic metals than the guideline values as a result of inadequate supply of treated water to communities (1). To date, the removal of all toxic metals from drinking water with a comprehensive technique has not been reported. Further populations are exposed to drinking water from taps inside the building, where the metal concentrations increase due to stagnation of water in the water distribution system, hot water tanks (HWTs) and plumbing pipes (PP) inside the building.

An adequate supply of pure safe drinking water is one of the major prerequisites for a healthy life, but waterborne disease is still a major cause of death in many parts of the world, particularly in children, and it is also a significant economic constraint in many subsistence economies. Discharges of toxic metals from industrial premises and sewage treatment works are point sources and as such are more readily identifiable and controlled; run off from agricultural land and from hard surfaces, such as roads, are not so obvious, or easily controlled (6).

Such sources can give rise to a significant variation in the contaminant load over time. There is also the possibility of spills of chemicals from industry and agriculture and slurries from intensive farm units that can contain pathogens (7). In some locations, badly sited latrines and septic tanks are a significant source of contaminations. Local industries can also give rise to contamination of water sources, particularly when chemicals are handled and disposed of without proper care. The run-off or leaching of nutrients into slow flowing or still surface waters can result in excessive growth of cyanobacteria or blue-green algae (4).

Many species give rise to nuisance chemicals that can cause taste and odour and interfere with drinking water. However, they frequently produce toxins, which are of concern for health, particularly if there is only limited treatment. Contamination can also take place in consumers' premises from materials used in plumbing, such as lead or copper, or from the back-flow of liquids into the distribution system as a consequence of improper connections. Such contaminants can be either chemical or microbiological. Drinking water treatment as applied to public water supplies can be carried out through coagulation and flocculation, filtration and oxidation. The most common oxidative disinfectant used is chlorine (8).

This provides an effective and robust barrier to pathogens and provides an easily measured residual that can act as a marker to show that disinfection has been carried out, and as a preservative in water distribution. The basis on which drinking water safety is judged is national standards or international guidelines. The most important of these are the WHO Guidelines for Drinking-Water Quality (8).

The Guidelines are now based on Water Safety Plans that encompass a much more proactive approach to safety from source-to-tap (9). A toxic metal refers to a relatively dense metal or metalloid that is recognized for its potential toxicity, especially in environmental contexts (10). The term has particular application to cadmium, mercury, lead, and arsenic, (11) all of which appear in the World Health Organization's list of ten (10) chemicals of major public concern. Other examples include manganese, chromium, cobalt, nickel, copper, zinc, selenium, silver, antimony and thallium.

In some communities where the water distribution network is made of alloys containing toxic metals, those who cannot afford bottled- or mineral water with controlled toxic metal concentrations have no alternative than to consume hand-dug well, borehole or tap water, Therefore, the possible contamination of drinking-water with toxic metals and subsequent accumulation are greatly increased (12). The quality control in drinking-water and detection of its toxic metals is an extremely critical issue for in order to maintain sound human health (13). Toxic metals can bioaccumulate in organisms as they are hard to metabolize (14).

Toxic metals can bind to vital cellular components, such as structural proteins, enzymes, and nucleic acids, and interfere with their functioning(15).

Past studies report toxic metals in drinking water, including their types and quantities, factors affecting metal concentrations, sources, human exposure, risk and removal. Despite significant progress, research is needed to ensure safe drinking water.

Symptoms and effects can vary according to the metal or metal compound, and the dose involved. Broadly, long-term exposure to toxic metals can have carcinogenic, central and peripheral nervous system and circulatory effects. For humans, among others affect reproduction especially toxic metals such as lead.

Studies from rodent models suggest that gonadotropin hormones (both LH and FSH) support the process of spermatogenesis by suppressing the proapoptotic signals and thus promoting spermatogenic cell survival. The Sertoli cells themselves mediate parts of spermatogenesis through hormone production. They are capable of producing the hormones estradiol and inhibin.

The Leydig cells are also capable of producing estradiol in addition to their main product, testosterone. Gonadotropinreleasing hormone $(\mathrm{GnRH})$ is mainly made in the preoptic area of the hypothalamus before traveling to the pituitary gland (16). Circulating levels of FSH, LH, prolactin and testosterone are vital for spermatogenesis and sexual function. Accumulation of toxic metals in the body is harmful for 
sexual function and reproduction. Therefore, the evaluation of some toxic metal levels of drinking water and its possible effect on reproductive hormones is important for public health information.

\section{MATERIAL and METHODS}

This is a retrospective case-control study of male participants consuming drinking water from hand dug well, borehole water and treated table water in Sabongida Ora, Edo State. Sabongida Ora is the headquarters of Owan West Local Government Area of Edo State. Sabongida Ora is located at Latitude $6.90 \mathrm{~N}$ and Longitude5.90E. It has a population of 99,056 according to National Population Commission of Nigeria of population census conducted in 2006.

Participants were gotten from the people living in the local government area. A total of 90 subjects consisting of 30 subjects who drink borehole water, 30 subjects who drink water from hand-dug well and 30 subjects who drink table water, aged between 18 and 45 years were recruited for this study.

Toxic metal concentration of water from 10 hand-dug wells, 10 boreholes, and treated water was determined. The levels of some toxic metal, trace element and reproductive hormones of Individuals who consumed water from these sources were evaluated. Serum follicle stimulating hormone (FSH), luteinizing hormone (LH), prolactin (PROL), estrogen (E2), progesterone (PROG), and testosterone (T) were analyzed using Enzyme linked Immunosorbent assay method. Blood lead $(\mathrm{Pb})$, cadmium $(\mathrm{Cd})$, serum zinc $(\mathrm{Zn})$ and copper $(\mathrm{Cu})$ were analyzed using atomic absorption spectroscopy (AAS).

The study was designed to evaluate the levels of some toxic metals, trace element and reproductive hormones in water consumers (hand-dug well, borehole and table water). The study was carried out within twelve (12) months (July 2018 June 2019). The sample size was determined using the sample size determination formula for Health studies (17) and the prevalence of hormonal abnormalities in occupational exposure subjects to toxic metal contamination (96.7\%) (18). Therefore a minimum of 60 participants and 30 nonoccupationally exposed healthy subjects were enrolled for the study

The protocol for the study was reviewed and approved by the ethics committee of the Edo State Ministry of Health. Informed consent form was given by the participants before the commencement of the study.

Healthy men within the reproductive age of 18-45 years, and are drinking water solely from hand dug well, borehole water and treated water were included in the study. Individuals on male contraceptive, or with testicular varicocele, long term medications, known HIV infected, chronic and serious systemic illness, steroid preparations, non-consented and smoking were excluded from the study.

Water Sample was collected from hand-dug wells, borehole and treated water source in clean-glass containers washed by soaking in $20 \%$ (v/v) Nitric acid for 24 hrs. Sampling was conducted early in the morning before water abstraction commenced by residents. Two separate samples per water source were collected for analysis. Blood samples were collected aseptically from the antecubital vein of the water consumers in the early hours of the day with sterile disposal syringe and needle and dispensed into anticoagulant bottle (prescreened for cadmium, lead, copper and zinc by vial assay) and plain bottles.

The sample in the plain bottle was allowed to clot at $2-8{ }^{\circ} \mathrm{C}$, and after clot retraction, it was centrifuged at 3000rpm for 10 minutes. The plasma was separated and stored properly in labeled container at $-20{ }^{\circ} \mathrm{C}$ for hormonal assay, and the whole blood was stored at $2-8{ }^{0} \mathrm{C}$ for maximum of one week for cadmium, lead, copper and zinc analyses Both qualitative and quantitative data were collected using a semi-structured selfquestionnaire. The questionnaire has three (3) sections. Section A (Socio Demographic characteristics), Section B (Exposure/Awareness/Protection), Section C. (Medical/family history). The questionnaire was distributed among male participants drinking water from hand-dug well and borehole water as well as treated water.

The reproductive hormones (Luteinizing hormones, Follicle stimulating hormone Prolactin hormones, testosterone, Estradiol and Progesterone hormone) were assayed with ELISA technique (Monobind Inc. Lake Forest, CA 92630, USA. The blood and water cadmium, lead, copper and zinc were analyzed using with Atomic absorption spectroscopy at the wavelength of $217.0(\mathrm{~Pb}), 228.8(\mathrm{Cd}), 324.8(\mathrm{Cu})$ and 213.9(Zn) respectively (Buck Scientific Model VGP-210, Germany).

Results obtained are presented as mean \pm standard deviation (SD). Data obtained were statistically analyzed using spss version 23.0 software. The comparison of the mean values of measured parameters among hand dug well, borehole and table water consumer was performed using unpaied Student ttest, Chi-Squared and Pearson correlation coefficient was used to test the relationship between toxic metals levels and reproductive hormones. The statistical significance level was set at $\mathrm{p}<0.05$

\section{RESULTS}

Table 1 shows the socio- demographic variables of the study participants. The age range, sex, educational status, body mass index and ethnicity $(\mathrm{p}<0.05)$ except marital status $(p>0.05)$ were significantly different between the water consumer than the control(treated table water).

Table 2 shows the comparison of reproductive hormones among water consumers. It was observed that levels of reproductive hormones in hand-dug well, borehole were significantly lower than treated table water $(\mathrm{P}<0.05)$.

Table 3 shows the comparison of toxic metals levels among water consumers. It was observed that the levels of toxic metals in hand-dug well, borehole water were significantly higher than treated table water $(\mathrm{p}<0.05)$.

Table 4 shows the correlation of reproductive hormones with toxic metals among water consumers.

It was observed that cadmium and lead were negatively correlated with FSH, LH, E2, Progesterone and testosterone except for prolactin but zinc and copper were positively correlated with FSH, LH, E2 and testosterone except in prolactin that showing a negative correlation 
Table 1: Distribution of Demographic Factors of Dug Well and Borehole Water Consumers

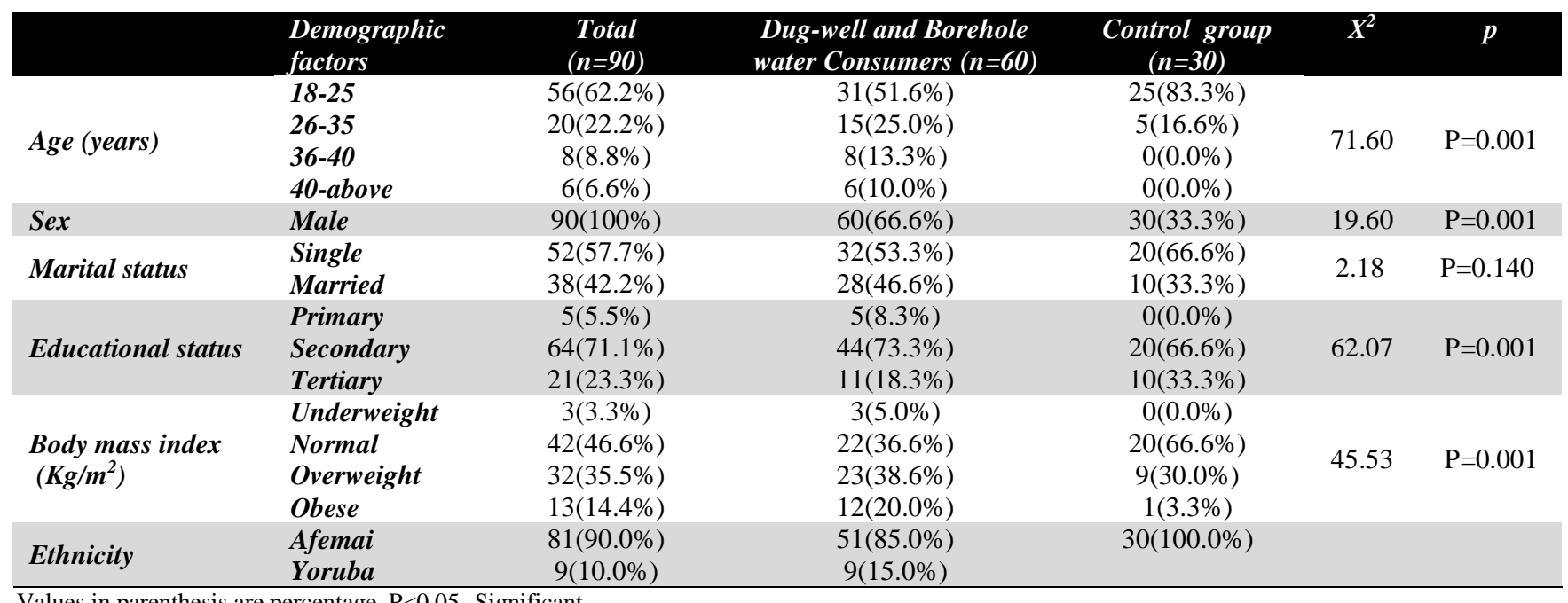

Values in parenthesis are percentage. $\mathrm{P}<0.05$ - Significant

Table 2: Comparison of reproductive hormones among different water consumers

\begin{tabular}{lccccc|} 
Parameters & $\begin{array}{c}\text { Dugwell water } \\
\text { consumer }\end{array}$ & $\begin{array}{c}\text { Borehole water } \\
\text { consumer }\end{array}$ & $\begin{array}{c}\text { Table water } \\
\text { consumer }\end{array}$ & F & P \\
\hline FSH(mIU/ml) & $2.61 \pm 0.39$ & $3.12 \pm 0.54$ & $5.83 \pm 0.39$ & 15.11 & $\mathrm{P}<0.05$ \\
LH(mIU/ml) & $1.31 \pm 0.21$ & $1.63 \pm 0.19$ & $6.98 \pm 0.34$ & 158.30 & $\mathrm{P}<0.05$ \\
E2(pg/ml) & $2.00 \pm 0.51$ & $2.67 \pm 0.43$ & $9.94 \pm 2.26$ & 10.38 & $\mathrm{P}<0.05$ \\
PROG(ng/ml) & $0.66 \pm 0.79$ & $1.82 \pm 0.16$ & $4.11 \pm 1.28$ & 4.02 & $\mathrm{P}<0.05$ \\
PROL(ng/ml) & $24.51 \pm 0.55$ & $19.63 \pm 1.02$ & $18.37 \pm 0.49$ & 19.91 & $\mathrm{P}<0.05$ \\
TESTO(ng/ml) & $2.42 \pm 0.48$ & $2.84 \pm 0.33$ & $6.54 \pm 0.27$ & 37.25 & $\mathrm{P}<0.05$ \\
\hline
\end{tabular}

Value are expressed in mean \pm SD, FSH- follicle-stimulating hormone, LH-Luteinizing hormone, E2-Estradiol, Prog-Progesterone, PROL-prolactin, TESTO- testosterone

Table 3: Comparison of metals among different water consumers

\begin{tabular}{|cccccc|}
\hline Parameters & $\begin{array}{c}\text { Dugwell water } \\
\text { consumer }\end{array}$ & $\begin{array}{c}\text { Borehole water } \\
\text { consumer }\end{array}$ & $\begin{array}{c}\text { Table water } \\
\text { consumer }\end{array}$ & F & P \\
\hline Cadmium(ug/dl) & $7.14 \pm 0.75$ & $6.10 \pm 0.32$ & $0.92 \pm 0.21$ & 46.27 & $\mathrm{P}<0.05$ \\
Lead(ug/L) & $40.43 \pm 2.77$ & $17.35 \pm 2.32$ & $4.64 \pm 0.48$ & 74.07 & $\mathrm{P}<0.05$ \\
Copper(ug/dl) & $90.63 \pm 1.51$ & $99.43 \pm 2.68$ & $97.90 \pm 2.23$ & 4.06 & $\mathrm{P}<0.05$ \\
Zinc(ug/dl) & $38.93 \pm 3.33$ & $45.60 \pm 2.35$ & $163.30 \pm 9.41$ & 139.54 & $\mathrm{P}<0.05$ \\
\hline
\end{tabular}

Table 4. Correlation of reproductive hormones with toxic metals among water consumers

\begin{tabular}{|lcc|}
\hline Parameters & R- value & P-value \\
\hline FSH/Cd & -0.275 & $\mathrm{P}>0.05$ \\
FSH/Pb & -0.398 & $\mathrm{P}<0.05$ \\
\hline FSH/Cu & 0.055 & $\mathrm{P}>0.05$ \\
\hline FSH/Zn & 0.422 & $\mathrm{P}<0.05$ \\
\hline LH/Cd & -0.622 & $\mathrm{P}<0.05$ \\
\hline LH/Pb & -0.493 & $\mathrm{P}>0.05$ \\
\hline LH/Cu & 0.033 & $\mathrm{P}>0.05$ \\
\hline LH/Zn & 0.745 & $\mathrm{P}<0.05$ \\
\hline E2/Cd & -0.230 & $\mathrm{P}>0.05$ \\
\hline E2/Pb & -0.250 & $\mathrm{P}>0.05$ \\
\hline E2/Cu & 0.065 & $\mathrm{P}>0.05$ \\
\hline E2/Zn & 0.412 & $\mathrm{P}<0.05$ \\
\hline Prog/Cd & -0.222 & $\mathrm{P}>0.05$ \\
\hline Prog/Pb & -0.055 & $\mathrm{P}>0.05$ \\
\hline Prog/Cu & -0.087 & $\mathrm{P}>0.05$ \\
\hline Prog/Zn & 0.229 & $\mathrm{P}>0.05$ \\
\hline Prol/Cd & 0.282 & $\mathrm{P}>0.05$ \\
\hline Prol/Pb & 0.443 & $\mathrm{P}<0.05$ \\
\hline Prol/Cu & -0.024 & $\mathrm{P}>0.05$ \\
\hline Prol/Zn & -0.404 & $\mathrm{P}<0.05$ \\
\hline Testo/Cd & -0.426 & $\mathrm{P}>0.05$ \\
\hline Testo/Pb & -0.400 & $\mathrm{P}>0.05$ \\
\hline Testo/Cu & 0.072 & $\mathrm{P}>0.05$ \\
\hline Testo/Zn & 0.542 & $\mathrm{P}<0.05$ \\
\hline
\end{tabular}

FSH- follicle stimulating hormone, LH-Luteinizing hormone, E2-Estradiol, Prog-Progesterone, PROL-prolactin, TESTO- testosterone, Cd-cadmium, $\mathrm{Pb}$ lead, $\mathrm{Cu}$ - copper, $\mathrm{Zn}$ - zinc, $\mathrm{P}<0.05$ - Significant, $\mathrm{P}>0.05$ - Non- significant 


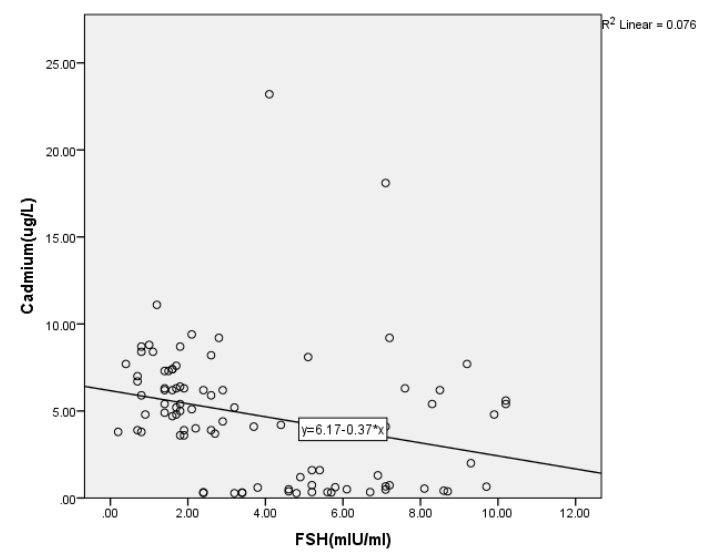

Figure 1: Scatterplot showing negative correlation of cadmium with follicle stimulating hormone $(\mathrm{FSH})(\mathrm{r}=-0.3 \mathrm{P}>0.05)$

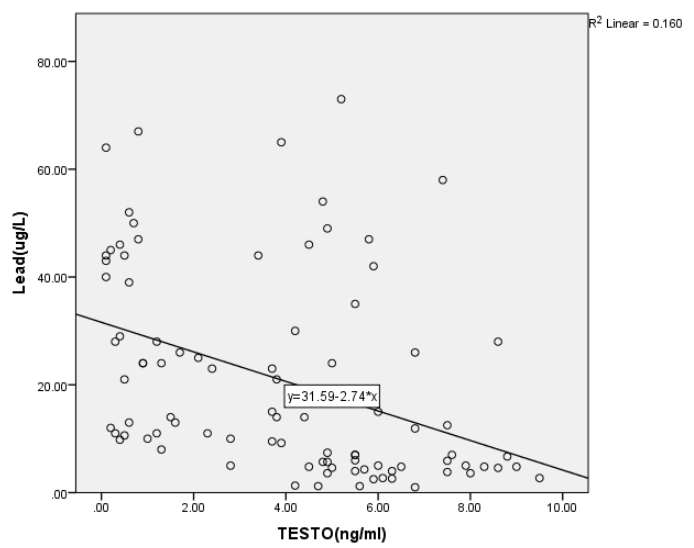

Figure 2: Scatterplot showing negative correlation of lead with luteinizing hormone $(\mathrm{LH})(\mathrm{r}=-0.4 \mathrm{P}<0.05)$

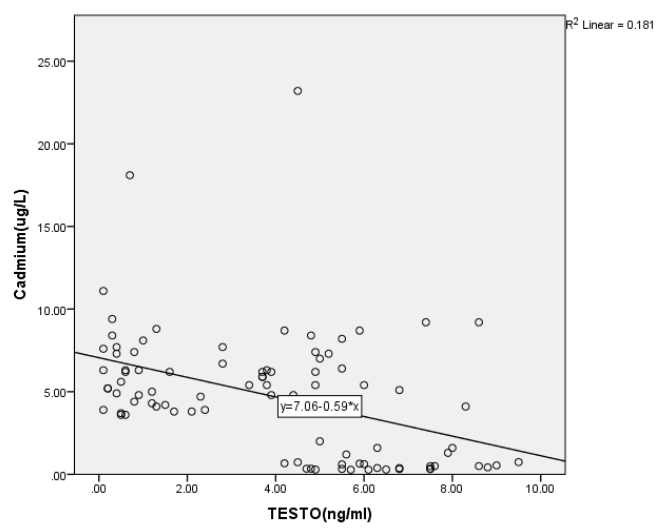

Figure 3: Scatterplot showing negative correlation of cadmium with testosterone (testo) $(r=-0.4, P>0.05)$

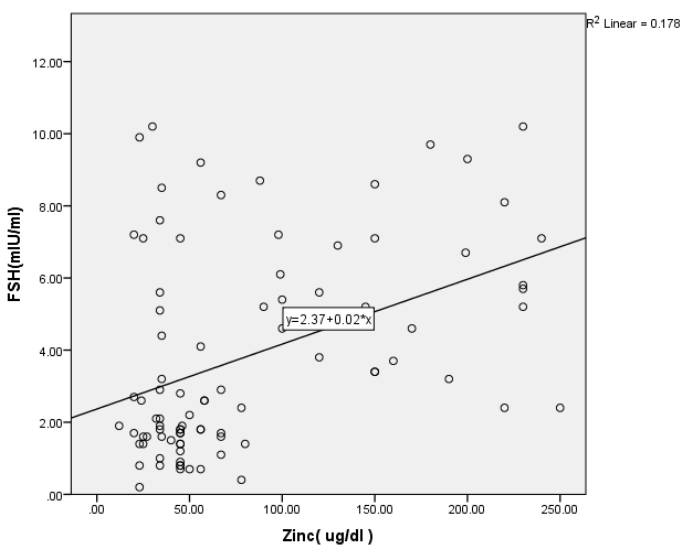

Figure 4: Scatterplot showing positive correlation of zinc on follicle stimulating hormone $(\mathrm{FSH})(\mathrm{r}=0.4, \mathrm{P}<0.05)$ 


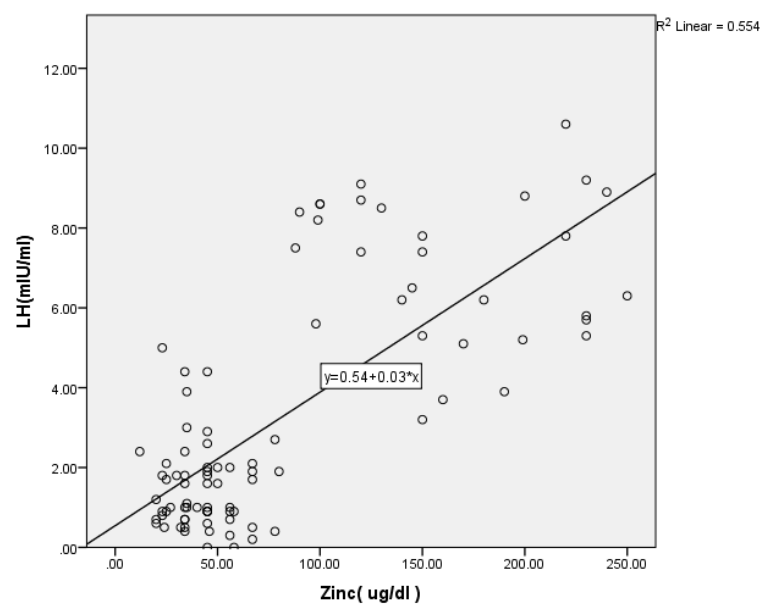

Figure 5: Scatterplot showing positive correlation of zinc on luteinizing hormone $(\mathrm{LH})(\mathrm{r}=0.7, \mathrm{P}<0.05)$

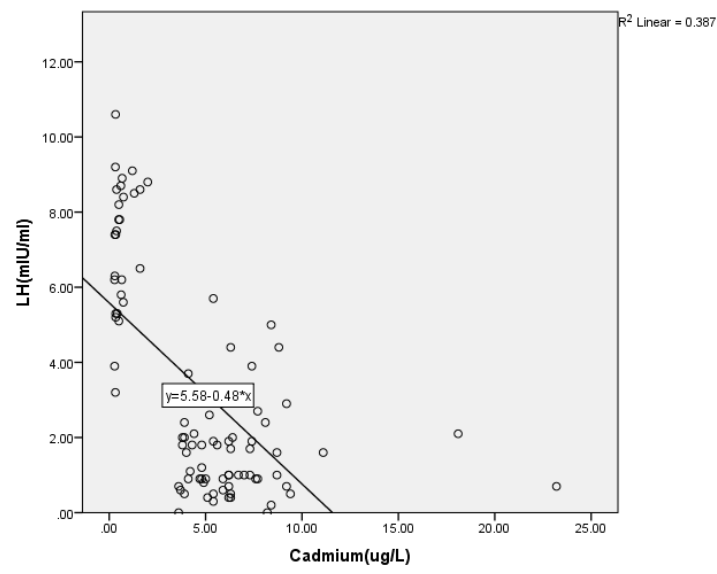

Figure 6: Scatterplot showing negative correlation of cadmium on luteinizing hormone $(\mathrm{LH})(\mathrm{r}=-0.6, \mathrm{P}<0.05)$

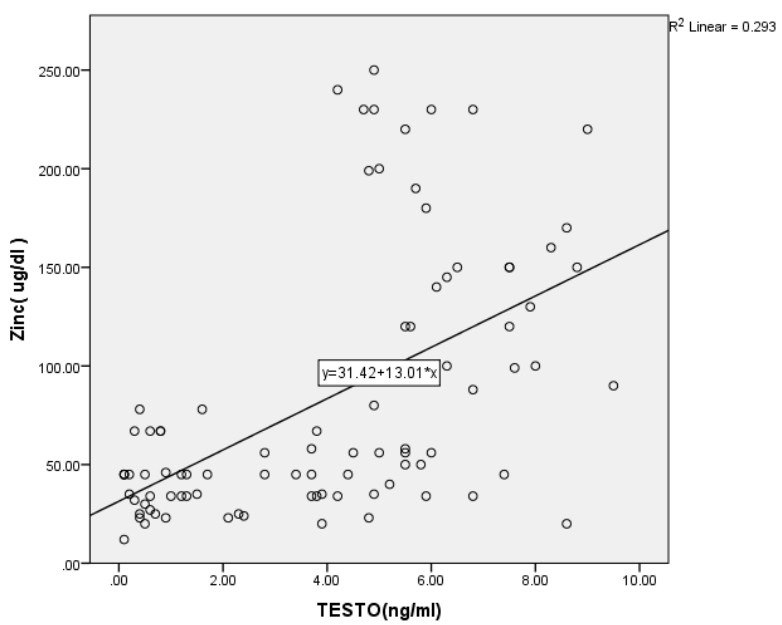

Figure 7: Scatterplot showing positive correlation of zinc on testosterone (testo) $(r=0.5, \mathrm{P}<0.05$

\section{DISCUSSION}

Nigeria belongs to the infertility belt of sub- Saharan Africa, and infertility has assumed a public health challenge. The causes of infertility in both males and female are multifactorial and the contributions of endocrine abnormalities have been reported (19). Toxic metal contamination in drinking water is a potential health risk to humans and has been reported to be the root cause of many chronic health challenges, including cancer, infertility, and organ damage.
The presence of toxic metals cannot be visualized with the naked eyes, but are detected in water through laboratory tests. This study conducted to determine $\mathrm{Cd}, \mathrm{Pb}, \mathrm{Zn}$ and $\mathrm{Cu}$ levels in hand-dug well, borehole and treated drinking water and the possible reproductive health effects on the consumers. In order to protect human health, guidelines for the presence of toxic metals in drinking water have been given by International Organizations such as WHO and European Union Commission (20). 
These organizations prescribed that toxic metal level in water should not be higher than the maximum permissible level in water as specified. Maximum contaminant level is an enforceable standard in numerical range value to ensure no adverse effect on human health. The upper limit of the highest level of a contaminant is the maximum allowed in a water system for a particular toxic metal.

The toxic metal concentrations in hand-dug well and borehole water showed that $\mathrm{Cd}$ and $\mathrm{Pb}$ concentrations were higher than WHO recommended permissible limits in drinking water. This is consistent with previous studies in some parts of Nigeria. For example, Momodu and Anyakora (21) observed that $19 / 30(84.21 \%)$ of underground sample water contained $\mathrm{Cd}$ concentration higher than the Maximum Contaminant Level $(0.003 \mathrm{mg} / \mathrm{L})$ with the maximum concentration of $0.098 \mathrm{mg} / \mathrm{L}(9.8 \mu \mathrm{g} / \mathrm{dL})$. The reported concentration is higher than observed in this study $(7.14 \mu \mathrm{g} / \mathrm{dL})$. The detected level, which is higher than the Maximum Contaminant Level, is of great concern since $\mathrm{Cd}$ has the potential to cause male infertility(22), cancers (23) and long biological half-life (24), leading to chronic organ damage (25). In this study, the concentration of $\mathrm{Cd}$ observed in hand-dug well and borehole water is above the recommended concentration permissible in drinking water by the WHO (26).

The concentration of $\mathrm{Pb}$ detected in hand-dug well and borehole water in this study was higher than the recommended permissible limit by WHO. The finding is consistent with that of Momodu and Anyakara (21) in Surulere, Lagos. The authors observed that 10 of the well water and 19 borehole water samples contained $\mathrm{Pb}$, and 6 of the well water and 12 of the borehole water samples contained levels above the Maximum Contaminant Level $(0.01 \mathrm{mg} / \mathrm{L})$ with the maximum concentration detected was $0.024 \mathrm{mg} / \mathrm{L}(2.4 \mu \mathrm{g} / \mathrm{dL})$. These findings are of concern since $\mathrm{Pb}$ can bio accumulate and affects the general body metabolism (27) as well as male infertility (28). Lead is also a neurotoxin and may be responsible for the most common type of human metal toxicosis (29). Also, some authors have associated $\mathrm{Pb}$ exposures even at low levels with and elevated blood pressure (30) and reduced intelligence quotient in children (31). Lead is a naturally occurring metal present in small quantities in the earth's crust. Although lead occurs naturally in the environment, human activities such as the use of fossil fuel, mining and manufacturing industries contribute to the release of high concentrations. The concentration of $\mathrm{Pb}$ observed in hand-dug well and borehole water was higher than in treated water and more than the quantity recommended in drinking water by the WHO. The permissible limit recommended by WHO for drinking water is $0.01 \mathrm{mg} / \mathrm{L}$.

From this study, it was observed that the concentration of $\mathrm{Pb}$ and $\mathrm{Cd}$ in the blood of hand-dug well and borehole water consumers was higher than consumers of treated table water. This finding is consistent with the other studies in Baghdad, Beirut, and Al-Najaf which reported that the blood $\mathrm{Pb}$ and other toxic metals were higher among exposed individuals $(32,33)$. Copper and zinc were lower in those that consumed water from hand-dug well, borehole than the treated table water. The higher blood level of toxic metals among the subjects may be traceable to drinking of contaminated water (hand-dugged well and borehole water) (34) since the respondents were occupationally exposed. The respondents reported that they have been consuming water from these sources for several years, being the only source of drinking water as at then of our study. Significant low values of reproductive (sex) hormones of the subjects that consume hand-dug well and borehole water than treated table water was also observed $(\mathrm{p}<0.05)$. From previous studies, it was observed that these toxic metals are potent endocrine disruptors and oxidative stress inducers (35) as well as the hypothalamo-pituitary-gonadal axis inhibitors (36,37,38). These glands have been shown to act with a common function in order to achieve a common goal of regulating reproductive and sex hormone production. The hypothalamic pituitarygonadal axis plays a critical part in the development and regulation of a number of the body's systems, such as the reproductive and immune systems. Any fluctuations in this axis cause changes in the hormones produced by each gland and have various local and systemic effects on the body. This axis controls development, reproduction, and aging in animals (39). Gonadotropin-releasing hormone $(\mathrm{GnRH})$ is secreted from the hypothalamus by GnRH- expressing neurons. The anterior portion of the pituitary gland produces Luteinizing hormone (LH) and Follicle Stimulating Hormones (FSH), and the gonads produce estrogen and testosterone. The male reproductive system depends upon the activities of these different hormones produced by various body glands and enters systemic circulation. Gonadotropin-releasing hormone is a tropic hormone produced by the hypothalamus and stimulates the anterior part of the pituitary gland to produce the $\mathrm{FSH}$, which stimulates the production of sperm in the testes of men, and LH, which causes the interstitial cells of the testes to produce the hormone testosterone. This concentration in relatively constant testosterone enters the systemic circulation of a healthy, reproductive-age male (40). Testosterone helps to produce and maintain the secondary sexual characteristics of the male and is also responsible for the sex drive as well as work with the FSH to stimulate the production of sperm. If the sperm levels are high, making nutrients for the developing sperm scarce, the testes release inhibin. The inhibin travels through the bloodstream to the brain, where it prevents the secretion of GnRH. In the absence of GnRH, FSH, and $\mathrm{LH}$ levels fall, and sperm production slows. This is one of the major mechanisms whereby male hormones are maintained at the relatively constant concentration (16). From the interrelationship of sex hormones and potential confounders, it was observed that lead $(\mathrm{Pb})$ was negatively associated with FSH and Estradiol and positively associated with prolactin which were statistically significant $(\mathrm{p}<0.05)$. It was observed that cadmium was negatively associated with $\mathrm{LH}$, which was statistically significant. This result is in line with the findings of other studies which negatively affect on LH (41). Zinc was shown to have a positive association with FSH, LH, Estradiol, and testosterone and a negative association with prolactin which were statistically significant $(\mathrm{p}<0.05)$. Therefore, the observed decrease in the serum levels of these reproductive hormones suggests that the associated increase observed in the serum levels of toxic metals among those that consumed water from hand-dug well and borehole could have caused impairment in the neuron-chemical secretory mechanisms along the hypothalamo-pituitary-gonadal axis responsible for the synthesis and secretion of these hormones. A negative relationship is therefore established between the serum level 
of toxic metals and the reproductive hormones of the subjects. This damage of reproductive hormones can result in the damage of the reproductive functions and capacities of affected subjects. The mean blood levels of toxic metals (lead and cadmium) of hand-dug water consumers and borehole water consumer were compared, it was observed that the concentration of toxic metals $(\mathrm{Pb}$ and $\mathrm{Cd}$ ) in the serum of hand-dugged well were higher than the borehole water consumers which was statistically significant $(\mathrm{p}<0.05)$. This finding is also consistent with the other studies $(42,43,44)$ that groundwater is contaminated as a result of its contact with soil, rocks, and plants and the constituents of these sources. Copper and zinc were higher in the borehole water consumers and statistically significant $(\mathrm{p}<0.05)$. The increase in the serum level of toxic metals among the hand-dug well water consumers is traceable to Industrial processes; generate wastes, which are mostly discharged into the environment. Industrial activities, especially electroplating, metal smelting and chemical industries and manufacturing processes, are sources of anthropogenic toxic metals in water. Poorly treated domestic, industrial and agricultural wastewater contains high concentrations of toxic metals, which are often discharged into the environment.

\section{CONCLUSION}

From this study, it is evident that consumption of contaminated water with toxic metals might pose reproductive health threat to consumers. This is as a result of the water not being treated for toxic metals and other impurities before consumption. This alteration in reproductive hormone levels may cause infertility and other disease conditions in men. In view of the dangers associated with the consumption of water contaminated with toxic metals and other impurities, it becomes necessary to ensure that water from boreholes and especially hand-dug wells are subjected to treatment for purification to make it free from toxic metals and other impurities. Enforcement of the recommended guidelines by WHO regarding the purity of drinking water is suggested.

Acknowledgement: The authors are particularly grateful to God, the giver of knowledge, and to the staff of University of Benin teaching hospital for their cooperation during the study

Author Contributions: Enehizena Osaro Ogie assisted in research design and initiation of the study. Fidelis Oyakhire assisted in literature review and data analysis. Egho Eseoghene Valentine assisted in sample collection. Cedric Odaro, Joy Akpesiri Egho, Ekomobong Effiong Idem and Ibhenbisa Ighedose Benjamin assisted in Laboratory analysis of the samples.

Financial \& competing interest's disclosure: The authors have no relevant affiliations or financial involvement with any organisation or entity with a financial interest in or financial conflict with the subject matter or materials discussed in the manuscript. This includes employment, consultancies, honoraria, stock ownership or options, expert testimony, grants or patents received or pending, or royalties.

Conflict of interest: The author declared no potential conflicts of interest with respect to the research, authorship, and/or publication of this article. This research did not receive and specific grant from funding agencies in the public, commercial, or not-for-profit sectors.

Ethical approval: The study was conducted according to the guidelines of the Declaration of Helsinki and approved by Local Ethical Committee.

\section{REFERENCES}

1. World Health Organization (WHO): Guidelines for drinking-water quality. Fourth edition World Health Organization, Geneva,2011, 7-9

2. US Environmental Protection Agency (USEPA): Regulated drinking water Contaminants Online database ,2015.

3. Central Intelligent Agency (C.I.A) :The World Fact book,2016.

4. Bryan GW, Langston WJ. Bioavailability, accumulation and effects of heavy metals in sediments with special reference to United Kingdom estuaries: a review. Environmental Pollution. 1992;76: 89 - 131

5. Alabdula'aly AI, Khan MA. Heavy metals in cooler waters in Riyadh, Saudi Arabia. Environmental Monitor Assess. 2009; 157: 23 - 28.

6. Adeyemi I, Chris D, Andrea C, Kate R, Peter B, Charlotte G, et al. Psychosomatic medicine .2013;75 (2), 211-221

7. Vodela JK, Renden JA, Lenz SD, Henney WH, kemppainen BW. Drinking water contaminations, Poultry Science.1997;76:1474-1492

8. World Health Organization (WHO): Working together for health. Geneva 2006;1-2.

9. Kolo BG, Jibrin MD, Ishaku IN. Elemental analysis of Tap and Borehole water in Maiduguri, semi arid region, Nigeria. Environ $\mathrm{J}$ of Sci.2009; 1(2) 26-29

10. Srivastava S, Goyal P. Decontamination of Toxic Metals from Waste water. Novel Biomaterials. 2010;12: 7 -9

11. Brathwaite RL, Rabone SD. Heavy Metal Sulphide Deposits and Geochemical Surveys for Heavy Metals in New Zealand. Jour of the Royal Soc of New Zealand. 1985;15(4): 363 - 370.

12. Mishr S, Martin L, Lalumière R, Williams, J. Personality and Individual Differences. 2010 ; 616-621.

13. Harvey PJ, Handley HK, Taylor MP. Identification of the sources of metal (lead) contamination in drinking waters in northeastern Tasmania using lead isotopic Compositions. Environ Sci and Pol Research. 2015; 22: $12276-12288$

14. Pezzarossa B, Gorini F, Petruzelli G. Heavy Metal and Selenium Distribution and Bioavailability in Contaminated Sites. A Tool for Phytoremediation. In Selim, HM. Dynamics and Bioavailability of Heavy Metals in the Rootzone. 2011;11: 93-128.

15. Landis WG, Sofield RM, Yu MH. Introduction to Environmental Toxicology: Molecular Substructures to Ecological Landscapes. (4th): 2000;CRC Press.p.23-28

16. Vander A, Sherman J, Luciano D. Human physiology: The Mechanisms of Body Function. (7th edition). Smith Jour of Medicine North Am. 56: $8-11$

17. Lwange SK, Lemeshow S.Sample size determination in health studies: A practical manual. IRIS, World Health Organization, 1991.

18. Emokpae MA, Oyakhire FO. Levels of some reproductive hormones, cadmium and lead among fuel pump attendants in Benin City, Nigeria. Afr Jour of Med and Health Sciences.2020; 19(6), 70-77

19. Emokpae AM, Uadia PO, Omale-Itodo A, Orok TN. Male infertility and endocrinopathies in Kano, Northwest, Nigeria: Ann of Afric Med .2007; 6:64-67 
20. Marcovecchio JE, Botte SE, Freije RH. Heavy Metals, Major Metals, Trace Elements. In: Handbook of Water Analysis. L.M. Nollet, (Ed.) 2nd Edn. London:CRC Press, 2007; pp: 275-311

21. Momodu MA, Anyakara CA. Heavy Metal Contamination of Ground Water: The Surulere Case Study. Res Jour Environ and Earth Sciences 2010;2(1): 39-43.

22. Emokpae MA, Adobor CA. Association of seminal plasma cadmium levels with semen quality in non-occupationally exposed infertile Nigerian males. $\mathrm{J}$ of Environ and Occupational Sciences.2015;3(4):40-43

23. Lauwerys RR. Health Effects of Cadmium. In: Trace Metal: Exposure and Health Effects. E. Di Ferrante, (Ed.). Oxford, England: Pergamon Press, 1979;page: 43-64.

24. Orisakwe OE, Igwilo IO, Afonne OJ, Maduabuchi JU ,Obi E, Nduka JC.Heavy metal hazards of sachet water in Nigeria. Arch of Environ and Occupational. Health.2006; 61(5): 209-213.

25. Hammer MJ, Hammer Junior MJ. Water Quality. In: Water and Waste Water Technology. 5th Edition. New Jersey: Prentice-Hall.2004; page: 139-159.

26. World Health Organization: Hazardous Chemicals in Human and Environmental Health: A Resource Book for School, College and University Students. World Health Organization, Geneva 2000; 4-6

27. Adepoju-Bello AA, Alabi OM. Heavy metals: A review. The Nigeria J Pharm. 2005;37: 41-45.

28. Emokpae MA, Adobor C, Ibadin K . Seminal Plasma levels of lead and mercury in infertile males in Benin City, Nigeria. International Journal of Medical Research and Health Sciences.2016; 5(1):1-6.

29. Berman E. Toxic Metals and Their Analysis.Philadelphia, PA: Hayde and Sons. 1980.

30. Zietz BP, Lap Suchenwirth JR. Assessment and management of tap water Lead contamination in Lower Saxon, Germany. Intern J of Environ Health Research,2007;17(6): 407-418

31. Needleman HL. The current status of childhood low-level lead toxicity. Neurotoxicology. 1993;14: 161-166

32. Al-Rudainy LA.: Blood lead level among fuel station workers. Oman Medical Journal. 2010;25: 208 - 211.
33. Al-Shamri AM, Nama RS, Radhi AW, Odda FM. Determination of Lead , Cupper, Iron , and Zinc in Blood of Fuel Station Worker at Al Najaf City. Iraq Academic Scient Journal. 2010;15: 1 - 10.

34. Gaur S, Agrawal S, Saxena S, Kumar GR, Kumar D. Biological Effect of Heavy Metal in Drinking Water samples of Western Uttar Pradesh region in India. Indian $J$ of Toxic Hazard Substance Environmental Engineering. 2012; 34: 7 - 17s

35. Buzcu-Guven B, Harriss R. Extent, impacts and remedies of global gas Flaring and venting. Carbon Management. 2012;3(1): 95 - 108

36. Akinloye O, Arowojolu AO, Shittu OB, Anetor JI. Cadmium Toxicity: A possible cause of male infertility in Nigeria Reproductive Biology.2006; 6:17 - 30.

37. Umeyama T, Ishikawa $\mathrm{H}$, Takeshima $\mathrm{H}$, Yoshi $\mathrm{S}$, Koiso K. A comparative study of seminal trace elements in fertile and infertile men. Fertility Sterility. 1986; 46: $494-499$

38. Makada MT, Amith S. Levels of Cadmium, Chromium, Nickel Manganese and Lead in normal and pathological human seminal plasma. Urologia, 2005;72: 461 - 464.

39. Corradi PF, Corradi RB, Greene LW. Physiology of the hypothalamic pituitary gonadal axis in the male. Urology Clinician; 2016;43(2): 151162.

40. Tesarik J, Bahceci M. Restoration of fertility by in-vitro spermatogenesis. Lancet 1999; 353(9152): 555-556

41. Telisman S, Colak B, Pizent A, Jurasoviæ J,Cvitkoviæ P. Reproductive toxicity of low-level lead exposure in men. Environ Res. 2007;105: 256

42. UNESCO : Ground Water Pollution. International Hydrological Programme. Guidelines for drinking water quality, 4th edition.2000

43. Nardia P, Fábio S, Evangelist AB, Luciano TB, Tatiana D, Saint`Pierre B, et al. Food Chemistry. 2009;112. Pages 727-732.

44. Hanuman -Reddy PM, Prasad AV, Reddy RV. Determination of heavy metals in Surface and Groundwater in and around.2012

Copyright (C) 2021 The Author(s); This is an open-access article distributed under the terms of the Creative Commons Attribution License (http://creativecommons.org/licenses/by/4.0), (CC BY NC) which permits unrestricted use, distribution, and reproduction in any medium, provided the original work is properly cited. International Journal of Medical Science and Discovery. 